\title{
"OUTSOURCING" MENGALIHDAYAKAN SDM UNTUK FOKUS PADA BISNIS UTAMA \& MENINGKATKAN EFISIENSI SERTA PRODUKTIVITAS
}

\author{
Oleh: \\ Arif Darmawan
}

\begin{abstract}
Dälam era globalisasi dan tuntutan persaingan dunia usaha yang ketat saat ini, maka perusahaan dituntut untuk berusaha meningkatkan kinerja usahanya melalui pengelolaan organisasi yang efektif dan efisien. Salah satu upaya yang dilakukan adalah dengan mempekerjakan tenaga kerja seminimal mungkin untuk dapat memberi kontribusi maksimal sesuai sasaran perusahaan. Untuk itu perusahaan berupaya fokus menangani pekerjaan yang menjadi bisnis inti (core business), sedangkan pekerjaan penunjang diserahkan kepada pihak lain. Proses kegiatan ini dikenal dengan istilah "outsourcing."
\end{abstract}

Kata Kunci : "Outsourcing", Efisiensi, Produktivitas

\section{A. PENDAhUlUAN}

Persaingan dalam dunia bisnis antar perusahaan sekarang ini membuat perusahaan harus berkonsentrasi pada rangkaian proses atau aktivitas penciptaan produk dan jasa yang terkait dengan kompetensi utamanya. Dengan adanya konsentrasi terhadap kompetensi utama dari perusahaan, akan dihasilkan sejumlah produk dan jasa yang memiliki kualitas dan daya saing di pasaran. Disamping itu perusahaan dituntut untuk meningkatkan kinerja usahanya melalui pengelolaan organisasi yang efektif dan efisien. Salah satu upaya yang dilakukan adalah dengan mempekerjakan tenaga kerja seminimal mungkin untuk dapat memberi kontribusi maksimal sesuai sasaran perusahaan. Untuk itu perusahaan harus berupaya fokus menangani pekerjaan yang menjadi bisnis inti (core business), sedangkan pekerjaan penunjang diserahkan kepada pihak lain. Sejalan dengan itu perusahaan berusaha untuk melakukan efisiensi biaya produksi (cost of production). Proses kegiatan diatas dikenal dengan istilah Outsourcing, dimana dengan sistem ini - perusahaan dapat menghemat pengeluaran dalam membiayai sumber daya manusia (SDM) yang bekerja di perusahaan yang bersangkutan 
Kecenderungan besar dalam proses bisnis yang mengarah pada efisiensi dan fokus pada bisnis inti telah membuka peluang yang sangat besar bagi perusahaan outsourcing. Dalam praktik dimancanegaa, pengelolaan bisnis outsorcing telah menjadi salah satu model yang terus dikembahgakan karena terbukti bisa meningkatkan produktivitas dan efisiensi.

Survey yang dilakukan oleh Forester Research Inc., sebuah lembaga penelitian yang berpusat di Amerika Serikat menyebutkan bahwa pada tahun 2010 sekurang-kurangnya 3,3 juta pekerjaan kerah putih atau white colar jobs dan sekitar US \$ 136 milliar gaji bakal berpindah dari AS kenegara-negara berbiaya lebih murah seperti : India, Malasyia, dan China. Selain itu sekitar 210 ribu pekerjaan non IT telah dialihkan dari Inggris kenegara-negara lain yang bisa menghasilkan penghematan sebesar US $\$ 5,35$ Milliar. Nilai Outsourcing khusus bidang SDM di Amerika Serikat yang meliputi pengelolaan gaji, rekruitmen, layanan informasi, dan pelatihan kini telah mecapai US $\$ 10$ Milliar. (Sumber: Iftida Yasar: sukses Impelemntasi OutSourcing)

Saat ini praktik outsorcing sudah berkembang luas dibanyak perusahaan. Sejalan dengan perlunya mereka beroperasi secara efisien dan fokus terhadap bisnis mereka. Perancis kini merupakan Negara yang paling berkembang dalam menerapkan outsourcing. Hampir seluruh perusahaan Perancis, dalam berbagai skala menerapkan outsorcing dalam menjalankan bisnisnya.

\section{B. DEFINISI "OUTSOURCING"}

Selama ini belum ada peraturan perundang-undangan yang secara tegas dan rinci memberikan definisi tentang outsourcing. Pengertian outsourcing dapat dilihat dalam ketentuan pasal 64 Undang-undang No 13 Tahun 2003 tentang ketenagakerjaan, yang isinya menyatakan adanya suatu perjanjian kerja yang dibuat antara pengusaha dengan tenaga kerja, dimana perusahaan tersebut dapat menyerahkan sebagian pelaksanaan pekerjaan kepada perusahaan lainnya melalui perjanjian pemborongan pekerjaan yang dibuat secara tertulis.

Definisi tentang outsourcing juga bisa ditemukan dalam keputusan presiden (Keppres) Nomor 18 Tahun 2000, pada pasal 6 dan pasal 28, yang menyebutkan suatu pola pengadaan yang mengalihkan sebagian kegiatan pengadaan barang atau jasa kepada penyedia barang atau jasa yang mempunyai .keahlian dibidangnya yang mencakup layanan kegiatan operasi, rencana kebutuhan barang, proses pembelian, proses kepabeanan, pengelolaan inventori, sistem suplai, dan distribusi.

Para ahli manajemen sumber daya manusia (SDM) dan praktisi outsourcing menafsirkan pengertian outsourcing secara beragam. Dalam pengertian umum, istilah outsourcing atau alih daya diartikan sebagai contrack (ivork out). Menurut Maurice Greaver (dalam Iftida Yasar) outsourcing (alih d.aya) dipandang sebagai tindakan mengalihkan beberapa aktivitas perusahaan dan hak pengambilan keputusannya kepada pihak lain (outside provider), dimana tindakan ini terikat dalam suatu kontrak kerjasama. 
Richardus Djokopranoto mendefinisikan bahwa outsourcing merupakan hasil samping dari business prosess reengineering (BPR), yakni perubahan yang dilakukan secara mendasar oleh suatu perusahaan dalam proses pengelolaannya, bukan hanya sekedar melakukan perbaikan. BPR juga merupakan pendekatan baru dalam manajemen yang bertujuan meningkatkan kinerja, yang sangat berlainan dengan pendekatan lain, yaitu Continuous improvement process.

Dapat juga dikatakan outsourcing sebagai penyerahan kegiatan perusahaan baik sebagian ataupun secara menyeluruh kepada pihak lain yang tertuang dalam kontrak perjanjian. Penyerahan kegiatan ini dapat meliputi bagian produksi, beserta tenaga kerjanya, fasilitas, peralatan, teknologi dan asset lain serta pengambilan keputusan dalam kegiatan perusahaan. Penyerahan kegiatan ini kepada pihak lain merupakan hasil dari keputusan internal perusahaan yang bertujuan meningkatkan kinerja agar terus kompetitif dalam menghadapi perkembangan ekonomi dan teknologi global. Seringkali outsourcing disamakan dengan jasa penyalur tenaga kerja. Sebènarnya outsourcing adalah pemindahan fungsi pengawasan dan pengelolaan suatu proses bisnis kepada perusahaan penyedia jasa. Ada tiga unsur penting dalam outsourcing, yaitu :

1. Pemindahan Fungsi Pengawasan

2. Pendelegasian tanggungjawab atau tugas suatu perusahaan

3. Menitikberatkan pada hasil atau output yang ingin dicapai oleh perusahaan

Dengan outsourcing pada jangka waktu tertentu perusahaan melepaskan pengelolaan suatu tugas, baik untuk kegiatan operasional sehari-hari maupun untuk pengelolaan sumber daya manusianya kepada pihak penyedia jasa. Pengawasan terhadap karyawan hanya dapat dilakukan oleh perusahaan penyedia jasa tadi. Selama masa periode pengalihan tugas, semua tanggungjawab dialihkan kepada pihak penyedia jasa. Mulai dari rekruitmen, pelatihan, masuk kerja, pengawasan kinerja, evaluasi kinerja, pengurusan administrasi cuti, sakit, dan sebagainya, hingga adanya srat peringatan bahkan pemutusan hubungan kerja dilakukan oleh perusahaan penyedia jasa.

Dari beberapa definisi yang dikemukaan diatas, terdapat persamaan dalam memandang outsourcing, yaitu adanya penyerahan sebagian kegiatan perusahaan pada pihak lain, yang diharapkan memberikan hasil berupa peningkatan inerja agar dapat lebih kompetitif dalam menghadapi perkembangan ekonomi dan teknologi global.

\section{MENGAPA "OUTSOURCING"?}

Persoalan klasik dalam mengelola perusahaan adalah dengan bertambah maju dan besarnya perusahaan, maka bertambah pula beban operasional yang harus ditanggung. Bertambahnya pelanggan mengakibatkan perusahaan harus menambah jumlah karyawan yang meladeni pelanggan tersebut. Perusahaan dapat mensiasati dengan jalan menambah jam kerja 
atau menambah kompensasi bagai karyawan yang mau bekerja lembur. Tetapi jalan pintas ini hanya akan bersifat sementara. Daya tahan fisik dan kemampuan manusia terbatas, jika dipaksakan maka pada akhirnya kinerja karyawan akan tetap menurun.

Kegiatan yang meningkat, target bertambah tetapi tidak boleh ada penambahan karyawan akan membuat para manajer kehabisan waktu dan tenaga untuk mensiasati dan mengatur bisnis agar tetap berjalan lancar

Jika perusahaan mau merekrut karyawan baru tetapi tidak boleh ada tambahan karyawan tetap, sementara jumlah pekerjaan bertambah banyak, maka jalan keluarnya adalah merekrut karyawan outsource. Jika pekerjaan itu bersifat sementara saja, maka tidak perlu merekrut karyawan tetap, melainkan berikan saja pekerjaan itu kepada perusahaan outsource. Jika pekerjaan secara alamiah tidak dapat dikerjakan secara terus menerus karena dapat berakibat terhadap kinerja atau kesehatan pelakunya, maka lebih baik pekerjaan itu diberikan kepada pihak ketiga. Perușahaan hanya fokus di core business dan menyerahkan fungsi pendukung usaha ketempat lain, dalam hal ini outsourcing menjadi pilihan strategis.

Ada beberapa alasan mengapa perusahaan perlu melakukan outsourcing, diantaranya adalah :

- Fokus pada core bisnis

- Perampingan organisasi

- Peningkatan produktivitas

- Pekerjaan musiman

- Produk baru

- Ingin membagi resiko

- Menyerahkan kepada pihak yang lebih kompeten

(Sumber: Iftida Yasar: sukses Impelemntasi Outsourcing)

\section{KAPAN OUTSOURCING DIBUTUHKAN ?}

Perusahaan harus jeli dalam membaca peluang dan mempunyai inovasi terus-menerus agar dapat berkelanjutan usahanya. Sebagai akibat semakin dinamisnya lingkungan bisnis, maka perusahaan harus semakin lincah dan responsif sehingga selalu mampu meyesuaiakan dengan lingkungan bisnis yang karakteristiknya serba cepat dan serba tidak pasti. Jika tidak, maka banyak perusahaan bangkrut akibat terlambat melakukan perubahan cara pengelolaan. Outsorcing merupakan salah satu solusi bahkan kadang-kadang merupakan satu-satunya solusi dari problem efisiensi dalam menghadapi koompetisi. Ada beberapa indikasi kapan outsorcing dibutuhkan, yaitu :

- Jika cara kerja yang dilakukan sudah tidak efisien

- Jika biaya operasional semakin tinggi

- Jika daya kompetisi rendah

- Jika sudah menggunakan berbagai cara tapi tetap tidak berhasil 
Untuk mengantisipași kontra yang terjadi dalam penggunaan outsourcing, maka dibuat Undang-undang No.13/2003 tentang Ketenagakerjaan, khususnya tentang hubungan Kerja, yang didalamnya terdapat pasal-pasal yang terkait langsung dengan outsourcing. Berikut dijabarkan isi dari undangundang tersebut.

- UU No 13 Tahun 2003 tentang ketenagakerjaan membagi outsorcing menjadi dua bagian, yaitu : pemborongan pekerjaan dan penyediaan jasa pekerja atau buruh. Pada perkembangannya dalam draft reviși undang-undang No.13 tahun 2003 tentang ketenagakerjaan, outsourcing mengenai pemborongan pekerjaan dihapuskan karena lebih condong ke arah sub-contracting pekerjaan dibandingkan dengan tenaga kerja.

- UU No 13 Tahun 2003, pasal 64 dinyatakan bahwa: perusahaan dapat menyerahkan sebagian pelaksanaan pekerjaan kepada perusahaan lainnya melalui perjanjian pemborongan pekerjaan atau penyediaan jasa pekerja atau buruh yang dibuat secara tertulis

- Sedangkan pasal 65 memuat ketentuan sebagai berikut: penyerahan sebagaian pelaksanaan pekerjaan kepada perusähaan lain dilaksanakan melalui perjanjian pemborongan pekerjaan yang dibuat secara tertulis (ayat 1) dan pekerjaan yang diserahkan kepada pihak lain, seperti yang dimaksud dalam ayat 1 harus memenuhi syarat-syarat sebagai berikut: .

$\rightarrow$ Dilakukan secara terpisah dari kegiatan utama

$\rightarrow$ Dilakukan dengan perintah langsung atau tidak langsung dari pemberi pekerjaan

$\rightarrow$ Merupakan kegiatan penunjang perusahaan secara keseluruhan

$\rightarrow$ Tidak menghambat proses produksi secara langsung. (ayat 2)

$\rightarrow$ Perusahaan lain (yang menerima penyerahan pekerjaan) harus berbentuk badan hukum ( ayat 3 )

$\rightarrow$ Perlindungan kerja dan syarat-syarat kerja dan syarat-syarat keja pada perusahaan lain sama dengan perlindungan kerja dan syarat-syarat kerja pada perusahaan pemberi kerja atau sesuai dengan peraturan perundangan

$\rightarrow$ Perubahan dan/atau penambahan syarat-syarat sebagaimana dimaksud dalam ayat (2) diatur lebih lanjut dengan Keputusan Menteri.

$\rightarrow$ Hubungan kerja dalam pelaksanaan pekerjaan sebagaimana dimaksud dalam ayat (1) diatur dalam perjanjian kerja secara tertulisa antara perusahaan lain dan pekerja/buruh yang dipekejakan.

$\rightarrow$ Hubungan kerja sebagaimana dimaksud dalam ayat (6) dapat didasarkan atas perjanjian kerja waktu tidak tertentu atau perjanjian kerja waktu tertentu apabila memenuhi persyaratan sebagaimana dimaksud dalam Pasal 59.

$\rightarrow$ Dalam hal ketentuan sebagaimana dimaksud dalam ayat (2) dan ayat (3) tidak terpenuhi, maka demi hukum status hubungan kerja pekerja/buruh dengan perusahaan penerima pemborongan beralih menjadi hubungan kerja pekerja/buruh dengan perusahaan pemberi pekerjaan. 
Arief Darmawan: Outsourcing...

- Pasal 66, Penyediaan jasa pekerja./buruh untuk kegiatan jasa penunjang atau kegiatan yang tidak berhubungan langsung dengan proses produksi harus memenuhi syarat sebagai berikut : Adanya hubungan kerja antara pekerja/buruh dan perusahaan penyedia jasa pekerj/buruh; Pasal 1 ayat 15. "Hubungan kerja adalah hubungan antara pengusaha dengan pekerja/ buruh berdasarkan perjanjian keja, yang mempunyai unsur pekerjaan, upah, dan perintah."

Pekerja dari perusahaan penyedia jasa pekerja tidak boleh digunakan oleh pemberi kerja melaksanakan kegiatan pokok atau kegiatan yang berhubungan langsung dengan proses produksi, kecuali untuk kegiatan jasa penunjang atas kegiatan yang tidak berhubungan langsung dengan proses produksi.

Pada dasarnya peraturan telah menentukan bahwa hanya pekerjaan yang "non-core" atau bukan pekerjaan utama yang dapat di-outsource. Pertanyaannya adalah bagaimana menentukan jenis pekerjaan yang utama dan yang bukan utama yang dapat di-outsource?

Yang dapat menentukan mana pekerjaan utama dan bukan utama adalah perusahaan itu sendiri. Bersama dengan tim manajemen perusahaan dapat menentukan dan membuat surat keputusan mengenai mana pekerjaan yang dianggap utama dan yang bukan utama. Ketetntuan ini dapat ditinjau kembali secara berkala sesuai dengan kebutuhannya.

Perlu diingat bahwa walaupun perusahaan mempunyai kewenangan untuk menentukan hal diatas, bukan berarti perusahaan dapat semena-mena dala menentukan pekerjaa yang dapat di-outsorce. Jangan hanya mempertimbangkan penghematan dari segi biaya saja, tapi melupakan pengembangan sumber daya manusia untuk membangun perusahaan. Outsoucing benarbenar hanya ditujukan untuk membantu kelancaran operasional sesuai kebutuhan

Berikut contoh-contoh pekerjaan yang bisa di-outsorce antara lain :

- Usaha pelayanan kebersihan (cleaning service) -

- Usaha penyediaan maanan (catering)

- Usaha tenaga pengamanan (security)

- Usaha jasa penunjang dipertambangan dan perminyakan

- Usaha jasa penunjang disektor perbankan, misalnya : call center, receptionis, data entry, IT, penjualan.

- Usaha jasa penunjang disektor telekomunikasi, misal: IT, call center, penjualan, data entry.

- Usaha dibidang rekayasa (engineering), misalnya : product development, technology development.

- Usaha dibidang SDM (human resource), misalnya : linier programming, job design, strategic staffing.

- Usaha dibidang keuangan (finance), missal : portfolio management, capital budgeting, relevant cost. 
- Usaha dibidangkomunikasi (public relation), missal : majalah internal, web maintenance.

- Usaha dibidang CSR

\section{G. SYARAT-SYARAT PERUSAHAAN OUTSOURCING}

- Harus berbadan hukum

- Mempunyai izin yang dipersyaratkan oleh instansi yang terkait (depnakertrans dan departemen kehakiman)

- Perlindungan kerja dan syarat-syarat kerja bagi karyawan outsource sekurang-kurangnya sama dengan karyawan perusahaan pemberi pekerjaan atau sesuai dengan peraturan perundangan yang berlaku

- Jika syarat diatas tidak terpenuhi, maka demi hukum status hubungan kerja berlaih ke perusahaan pemberi pekerjaan.

- Mempunyai dana yang cukup agar dapat mendanai bisnisnya, terutama bagi pembayaran terlebih dahulu gai karyawan outsouce

- Mempunyai pengalaman dibidang sumber daya manusia dan bisnis terkait

\section{H. POLA HUBUNGAN KERJA KARYAWAN OUTSOURCING}

Hubungan kerja dapat berbentuk perjanjian kerja waktu tertentu (PKWT), atau Perjanjian Kerja Waktu Tidak Tertentu (PKWTT). Perjanjian kerja dengan perusahaan pemborongan pekerjaan diatur secara tertulis. Jika bentuk perjanjian kerjanya tidak seperti yang diatur diatas, maka demi hukum hubungan kerja karyawan outsource beralih dengan perusahaan pemberi pekerjaan (PKWT atau PKWTT)

Hendaknya perusahaan pemberi kerja atau pengguna tidak terikat dengan karyawan outsource tersebut secara langsung. Artinya, jangan menunjuk secara langsung pekerjaan yang hanya dapat dilaksanakan oleh karyawan outsource tertentu. Hal ini untuk menghindari adanya resiko diperpanjangnya kontrak karyawan tersebut yang melebihi dari peraturan yang berlaku, sehingga mengakibatkan risiko hubungan kerja beralih keperusahaan pemberi kerja atau pengguna. Lebih baik dan aman dari segi hukum adalah mendapatkan suatu standar pelayanan untuk pekerjaan tertentu, sehingga siapapun yang mengerjakannya akan mendapatkan hasil kerja yang sama.

\section{KUNCI SUKSES PELAKSANAAN OUTSOURCING}

Salah satu langkah penting dalam strategi bisnis untuk meningkatkan daya saing ditengah kancah industri yang ketat bagi banyak perusahaan saat ini adalah kembali focus pada kemampuan akar. Disisi lain, perusahaan harus pula bisa melepaskan kegiatan lain yang tidak banyak terkait dengan kompetensinya kepada pihak lain melalui kemitraan kerja atau penugasan kepada pihak ketiga. 
Oleh karena itu, untuk mendaptkan perusahaan outsourcing yang berkualitas dan kredibel, perusahaan pengguna bisa mendapatkannya melalui berbagai macam cara, seperti menghubungi asosiasi, mencari pada situs SDM, majalah bisnis dan SDM, referensi dari perusăhaan lain, peserta seminar outsourcing, referensi konsultan dan tender. Peru'sahaan yang telah mendapatkan calon-calon perusahaan penyedia dari berbagai sumber diatas sebaiknya mengedakan tẹnder ntuk memilih yang terbaik dilihat dari harga, jenis pelayanan, serta kualitas pelayanan.

Dálam konteks ini, outsourcing sebagai salah satu fasilitas yang bisa membantu perusahaan untuk focus pada kompetensinya, sekaligus menjalankan fungsi usaha dengan lebih efektif bisa menjadi pilihan. Outsourcing bukan kemitraan usaha, melainkan pendelegasian tangguung jawab suatu tugas perusahaan, yang meliputi kegiatan operasional perusahaan seharihari, pengelolaan sumber daya, serta pengawasan keseluruhan proses kerja kepada pihak penyedia jasa dengan menitikberatkan pada output atau hasil yang diinginkan oleh perusahaan pengguna jasa. Seperti telah disampaikan diawal, outsourcing berbeda dengan penyalur tenaga kerja yang umumnya hanya mengelola penyediaan tenaga kerja, sedangkan keseluruhan proses kerja serta pengawasannya masih ditangani perusahaan pengguna jasa.

Karena outsourcing mencakup proses kerja suatu fungsi usaha yang bermuara pada performa perusahaan secara keseluruhan, maka sebelum memanfaatkan jasa outsourcing amatlah penting bagi kita untuk memastikan bahwa penyedia jasa mampu memenuhi persyaratan legall, skill,dan teknis yang memadai sehingga dapat menjalankan perannya dengan baik. Namun, faktor lain yang juga penting untuk dipertimbangkan adalah langkah-langkah jitu dari sisi perusahaan dalam rangka pemilihan penyedia jasa outsourcing itu sendiri.

Menurut Maurice F Greaver (dalam Iftida Yasar), ada beberapa langkah penting yang harus diperhatikan sebelum sebuah perusahaan mengimplementasikan outsourcing. Langkah-langkah tersebut antara lain: perencanaan, pemilihan strategi, analisis biaya, pemilihan pemberijasa, tahap negosiasi, transisi sumber daya manusia, serta pengelolaan hubungan.

\section{J. PEMBAGIAN PERAN DENGAN PERUSAHAAN OUTSOUURCING}

Ada hal dasar penting yang sering terlewatkan dalam menjalin kemitraan antara perusahaan pengguna jasa dengan perusahaan penyedia jasa outsourcing, yaitu persepsi atau cara pandang perusahaan pemakai jasa tehadap pihak ketiga. Ini menjadi sangat penting karena akan mendasari bagaimana selanjutnya kerja sama akan dilaksanakan

Dalam kemitraan outsourcing, perusahaan sebaiknya memandang pihak ketiga sebagai business partner dan bukan sekedar supplier. Te rutama untuk . meingingat bahwa kerjsa sama ini menyangkut pengelolaan SDM yang relatif lebih sulit dikelola dibandingkan dengan, misalnya mengelola barang. Selain itu pelu dipahami juga bahwa keberhasilan maupun kegagalan pihak ketiga akan berpengaruh terhadap kinerja bisnis perusahaan. 
Konsḳuensi dari kemitraan yang berformat business partner adalah ădanya pembagian peran yang jelas antara perusahaan pengguna dengan penyedia jasa. Sehingga masing-masing pihak memiliki tanggungjawab ỹang sama beșar terhadap tercapainya hasil yang diharapkan. Pembagian $\therefore$ - $-m$ itu bersifat unik dạn sangat bergantung pada kebutuhan perusahaan serta kemampuan perusahaan penyedia jasa outsourcing.

Namun secara umum, pembagian peran yang jelas antara perusahaan pengguna dengan penyedia jasa dapat dijelaskan bahwa penyedia jasa outsourcing hanya mampu menjalankan fungsinya sebagai konsultan dan administratife expert, technical competency expert and culture developer, serta sebagai system and procedure expert.

\section{J. KESIMPULAN}

Kondisi dunia usaha saat ini yang serba cepat dan tidak pasti memang mengharuskan perusahaan untuk bergerak lincah dan responsif dan menyesuaikan dengan perubahan lingkungan bisnis. Banyak perusahaan bangkrut akibat terlambat melakukan perubahan cara pengelolaan.

Sejalan dengan itu, salah satu langkah penting dalam strategi bisnis untuk meningkatkan daya saing ditengah kancah industri yang ketat bagi banyak perusahaan saat ini adalah kembali focus pada kemampuan akar. Disisi lain, perusahaan harus pula bisa melepaskan kegiatan lain yang tidak banyak terkait dengan kompetensinya kepada pihak lain melalui kemitraan kerja atau penugasan kepada pihak ketiga. Karena itu, outsourcing merupakan salah satu solusi, dari problem efisiensi perusahaan dalam menghadapi persaingan bisnis.

Untuk mendaptkan perusahaan outsourcing yang berkualitas dan kredibel, perusahaan pengguna bisa mendapatkannya melalui berbagai macam cara, seperti menghubungi asosiasi, mencari pada situs SDM, majalah bisnis dan SDM, referensi dari perusahaan lain, peserta seminar outsourcing, referensi konsultan dan tender. Perusahaan yang telah mendapatkan calon-calon perusahaan penyedia dari berbagai sumber diatas sebaiknya mengedakan tender untuk memilih yang terbaik dilihat dari harga, jenis pelayanan, serta kualitas pelayanan.

\section{DAFTAR PUSTAKA}

Ardi-lamadi.blogspot.com.Susahnya-bekerja-menjadi-outsource

Chandra Suwondo, Outsourcing; Implementasi di Indonesia, Elex Media Computindo, Jakarta,

Hamzah, Praktek Outsourcing Rugikan Pekerja, FDK, UINJKT Online "Hadang Outsourcing dengan Framework Agreemenf', www.hukumonline.com). 
Iftida Yasar, Sukses Implementasi Outsourcing, Seri Manajemen SDM, PPM 2008

Muzni Tambusai, Pelaksanaan Outsourcing (Alih Daya) ditinjau dari aspek hukum ketenagakerjaan tidak mengaburkan hubungan industrial, http:// www.nakertrans.go.id/arsip berita/naker/outsourcing.php.

Nur Cahyo, Pengalihan Pekerjaan Penunjang perusahaan dengan Sistem Outsourcing (Alih Daya) Menurut Undang-undang No. 13 tahun 2003 Tentang Ketenagakerjaan (Studi Kasus pada Asuransi Astra Buana), Tesis Magister Hukum FHUI, Depok, 2006, hal.56.

"Outsourcing, Pro dan Kontra" http://recruitmentindonesia.wordpress.com

“Outsourcing, Riset Manajemen, PPM

"Outsource dipandang dari sudut perusahaan pemberi kerja", http://www. apindo.or.id

Pan Muhammad Faiz, , Tinjauan Yuridis terhadap Undang-undang Nomor 13 Tahun 2003 tentang Ketenagakerjaan, Jumal Hukum

Paket Kebijakan Perbaikan Iklim Investasi memuat hal-hal yang dituntut untuk dilakukan revisi dalam Undang-Undang Nomor 13 Tahun 2003 yaitu : Pemutusan Hubungan Kerjam Perjanjian kerja Waktu Tertentu,

_- - Perhitungan Pesangon, ljin tenaga Kerja Asing dan istirahat panjang.

Pasal 64 Undang-Undang Nomor 13 Tahun 2003 Tentang Ketenagakerjaan,

"Seputar Tentang Tenaga Outsourcing", http://malangnet.wordpress.com)

Soaring Eagle, Outsourcing-alih-daya-dan-pengelolaan-tenaga-kerja-padaperusahaan-tinjauan-yuridis-terhadap-undang-undang, on February 1, 2010 gofartobing.wordpress.com

Wirawan, Rubrik Hukum Teropong,Apa yang dimaksud dengan sistem outsourcing?,http://www.pikiran rakyat.com

Yenis Simanjuntak, Bisnis Outsourcing dalam ulasan Bisnis Indonesia RI

R.Djokopranoto, Outsourcing (Alih Daya) dalam UU No.13/2003 tentang Ketenagakerjaan (Perspektif Pengusaha), Materi Seminar disampaikan pada Seminar Outsourcing: Process and Mangement, World Trade Center Jakarta,13 -14 Oktober 2005, hal.5. 